\title{
THE REPRESENTATION OF WOMAN'S OPPRESSION IN LISA SEE'S SNOW FLOWER AND THE SECRET FAN
}

\author{
REPRESENTASI PENINDASAN PEREMPUAN DALAM NOVEL SNOW FLOWER \\ AND THE SECRET FAN KARYA LISA SEE
}

\author{
Azara Nafia Irmadani ${ }^{1}$, Supiastutik ${ }^{2 *}$, Irana Astutiningsih ${ }^{3}$ \\ ${ }^{1}$ Alumni of Faculty of Humanities, Universitas Jember \\ ${ }^{2,3}$ Faculty of Humanities, Universitas Jember \\ *Corresponding Author: supiastutik.sastra@unej.ac.id \\ Informasi Artikel: \\ Dikirim: 19/8/2018; Direvisi: 28/10/2019; Diterima: 18/11/2018
}

\begin{abstract}
Snow Flower and The Secret Fan is one type of fiction written by Lisa See in 2005. Snow Flower and The Secret Fan tells about the lives of Chinese women in the nineteenth century where women's position was subjugated. In that era, there was a tradition that required women to tie their feet when they were young then caused them to endure unbearable pain because of a foot-binding. By wrapping their feet tightly, they can get married and improve their social status and bring them to a better life. Foot-binding is a sexually pleasure for men to achieve sexual satisfaction. In addition, in that era women were not permitted to get education like men. This problem was the impact of the Patriarchal culture. In the Patriarchal culture, there is a Confucian teaching that is used as a way of life for Chinese people. The teaching requires women to obey men: father, husband, and later their sons. Therefore, Chinese women live as a second-class. In conducting this research, the author uses Representation Theory by Stuart Hall. Research shows that female oppression is clearly illustrated in the novel through footbinding. Lisa See vividly describes the real conditions of women's oppression in China in the Snow Flower novel and The Secret Fan.
\end{abstract}

Keywords: foot-binding, patriarchal culture, representation, woman's oppression

\section{Abstrak}

Snow Flower and The Secret Fan adalah salah satu jenis novel fiksi yang ditulis oleh Lisa See pada tahun 2005. Snow Flower and The Secret Fan menceritakan tentang kehidupan perempuan Cina di abad kesembilan belas dimana posisi perempuan lebih rendah daripada laki-laki. Di masa itu, ada sebuah tradisi yang mengharuskan mereka mengikat kaki dan memaksa mereka untuk menahan sakit tak tertahankan karena pengikat kaki. Dengan mengikat kaki, mereka dapat menikah dan memperbaiki status sosial serta membawa mereka ke kehidupan yang lebih baik. Kaki yang diikat menjadi kesenangan seksual bagi kaum laki-laki untuk mencapai kepuasan seksual. Selain itu, mereka tidak diijinkan untuk mendapatkan pendidikan seperti kaum laki-laki. Masalah tersebut merupakan dampak dari budaya Patriarkal. Dalam budaya Patriarkal, terdapat ajaran Confucian yang dijadikan pedoman hidup bagi masyarakat Cina. Ajaran tersebut menuntut para perempuan untuk mematuhi laki-laki: ayah, suami, dan nantinya anak laki-laki mereka. Maka dari itu, para perempuan Cina hidup sebagai rakyayt kelas kedua. Dalam melakukan penelitian ini, penulis menggunakan teori Representasi oleh Stuart Hall. Penelitian membuktikan bahwa penindasan wanita digambarkan dengan jelas dalam novel 
berupa pengikat an kaki. Lisa See secara realistis menggambarkan kondisi nyata penindasan wanita di Cina dalam novel Snow Flower and The Secret Fan.

Kata kunci: pengikatan kaki, budaya patriarki, representasi, penindasan wanita

\section{INTRODUCTION}

Woman's oppression is one of the issues which occurs for centuries without any concrete solution to solve it yet. Woman's oppression becomes one of serious problems which still occur in present days. Many stories about oppression toward women are still found in society so it can prove that oppression of women still do exists even be widespread. The woman's oppression usually happens in the country in the patriarchal control.

In the $19^{\text {th }}$ century, Chinese society adheres to patriarchal culture. The presence of women in traditional Chinese society is not an easy life. It exist rules and norms that distinguish between men and women. Women in Chinese culture are described as someone who must be obedient, polite, and loyal to her husband. It shows that the position of women in traditional Chinese families is dominated by men, especially for those from poor families. In poor families, girls are sold as slaves to wealthy families. They were assigned to work on all household matters.

Woman's oppression has become the point of the topic. Many authors of literary works describe the topic through their works. One of them is Lisa See. Lisa See is an American writer and novelist who was born in Paris in 1955, but was raised by her mother, writer Carolyn See, in Los Angeles, California. Her father lived in Chinatown and she spent a lot of time there. In his work, Lisa See tells a lot about women's lives and Chinese culture. She is the writer of Snow Flower and The Secret Fan (SFTSF) were published in 2005. This novel shows that female oppression still exists in the $19^{\text {th }}$ century in China. Moreover, by applying theory of Representation by Stuart Hall (1997) which emphasize to find the discourse of woman's oppression faced by Lily as the main character of the novel. It is also supported by using the theory of woman's oppression by Iris Marion Young. By reading this novel, the writer tries to explore the female main character who gets the oppression in Patriarchal culture. Lily portrayed the condition of women in the part of village in Patriarchal culture and shows the women's position in which they do not get the same opportunities as men.

\section{RESEARCH METHODOLOGY}

This study applies a qualitative research. The data are divided into primary data and secondary data. The primary data are taken from the Snow Flower and the Secret Fan novel by Lisa See, including sentences, dialog, narration, etc. The secondary data are taken from another books, website, and journals related to the representation of woman's oppression.

After the data have already been collected, the next step is processing and analyzing data. The data can be processed and analyzed based on research questions. Data processing is started by categorizing and verifying the data taken from Snow Flower and The Secret Fan. It is related to the woman's oppression in the novel. These data are collected from the data will be in the form of statements, narration and dialogue about woman's 
oppression especially foot-binding.

There are two research questions that will be discussed in this research. The analysis of the first research question is The Representation of Woman's Oppression in the novel. The second is the critical position of the author related to woman's oppression whether the author support, oppose or negotiate to the existence of woman's oppression especially foot-binding.

\section{RESULT AND DISCUSSION}

Social issues that exist in society have a history of certain events that a reculturally constructed in society. A meaning of the social issues is built up in the society. The meaning that has been constructed in the society is absorbed by people to be their point of views towards any social conflict such as woman's oppression. Woman's oppression means the bed treatment toward woman including to force her by taking her freedom. In the novel Snow Flower and The Secret Fan constructs foot-binding discourse of woman's oppression.

Levy (2001), foot- binding was traditional action of practicing tight binding to the feet of young girls to change the shape and size of their feet. This practice was found among upper class court dancers during the Five Dynasties and Ten Kingdoms period in $10^{\text {th }}$ century China, then gradually became popular among the elite during Song dynasty. Foot-binding eventually spread to most social classes by the Qing dynasty and the practice finally came to an end in the early $20^{\text {th }}$ century. Bound feet were at one time considered a status symbol as well as a sign of beauty. Yet, foot-binding was a painful practice and significantly limited the mobility of women, resulting in lifelong disabilities for most of its subjects. Feet altered by binding were called lotus feet. Foot-binding was practiced in different forms, and the more severe form of binding may have been developed in the 16th century. The prevalence and practice of foot-binding however varied in different parts of the country.

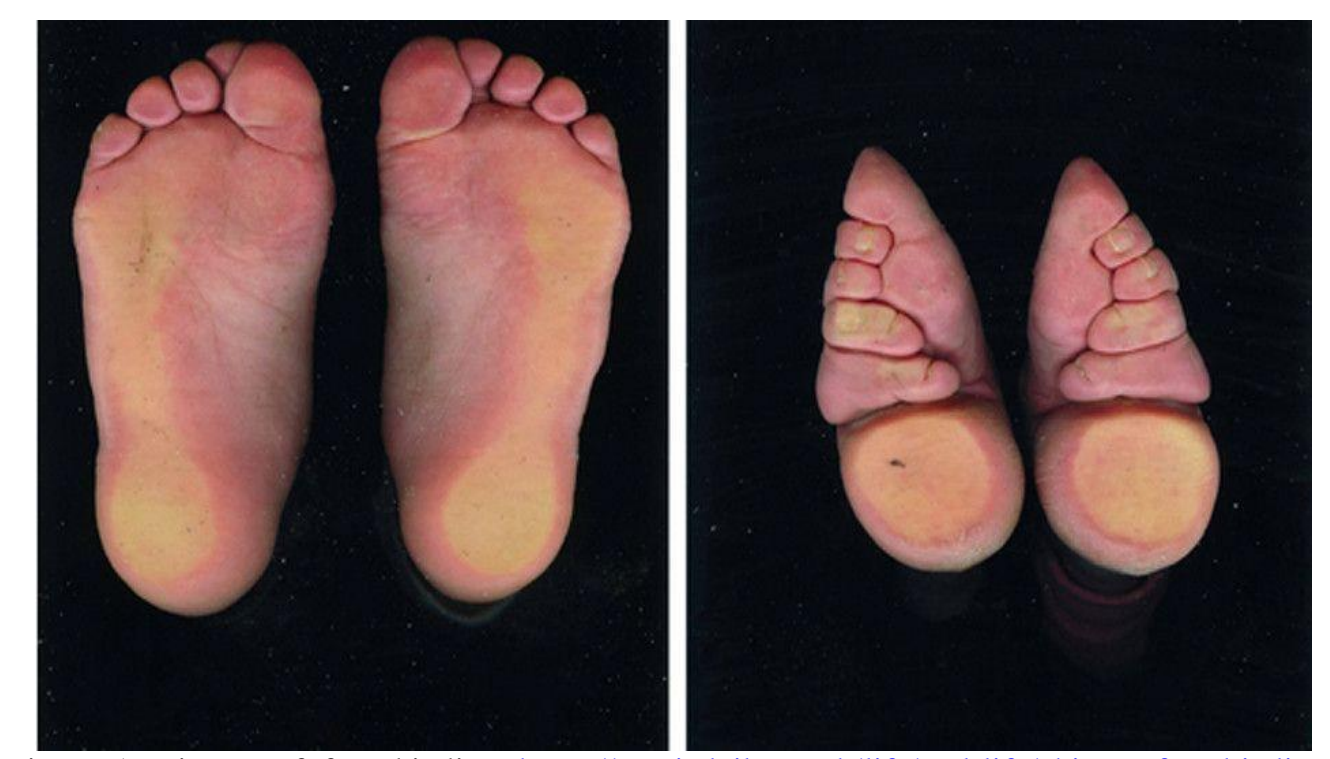

Picture 1. Picture of foot binding https://graziadaily.co.uk/life/real-life/chinese-foot-bindingpictures/Accessed on July $6^{\text {th }}, 2019$ 
Novel Snow Flower and The Secret Fan is set in Southern Hunan Province, a country in China. Lisa See uses Lily's characterization to represent a five years old Chinese woman trying to survive in a patriarchal culture. Chinese woman had to do a painful tradition of foot-binding. This tradition was initially only followed by women from noble families during the Han dynasty with the aim of showing their social status. Living in patriarchal culture in which men were superior to women, it is make women have to obey the culture. Women followed all the rules in order to survive under patriarchal culture. By doing footbinding, a woman will be considered beautiful and has an attraction. They will get recognition from the community in the form of the lotus feet designation which is believed to be a symbol of Chinese women's beauty. After foot-binding is done, she just spends her youth at the upstairs woman's chamber. Every day she learns to sew, weave, make shoes and carry out the activities of women. She is forced to spend her times to carry out the activities until she meets her husband through arranged marriages.

Rosenlee (2006), the practices of foot-binding in the nineteenth century in China will be discussed in relation to their social function ruled in Chinese society. Social function served to standardize the social value of a society. Social function deals with how certain traditional practices are created and how they serve to standardize how the person is expected to live, think, act well in the society. The Chinese women in the novel had already internalized very well the values of their society and knew how they should respond towards the cultural phenomena of foot-binding and lack of access to education. The main character in the novel, Lily, obeyed all the rules in her society without confronting at all. Lily realized as Chinese women, she was obliged to obey her father, her husband, and her son.

The writers mentioned that the Representation Theory means using the language as a media to communicate, to inform, or to represent what thing in our head. Thus, the writers use the representation theory to represent the five faces of oppression in the novel experienced by Lily as the main female character and it will be supported by the theory of woman's oppression by Iris Marion Young. In Young's theory, she mentioned five criterions about woman's oppression, there are: Exploitation, Marginalization, Powerlessness, Cultural Imperialism, and Violence. From these five criterions, the writers found only three parts, there are: Powerlessness, Cultural Imperialism, and Violence.

\section{Powerlessness}

In Chinese society, women are recognized as weak creatures. In the society, women do not have the same rights or strength as men. This happened because Chinese women had to conform to their culture or to what values believed by the society. The culture will be explained later as Three Obedience and Four Virtues, still sees that women are vulnerable. For that reason, it can be said that women become powerless in determining their lives. As maintained by Blake (1989), powerlessness is a matter about lacking authority or power. Lily as the main character of the novel does not have any ability to go against the culture of patriarchy. She has to comply with the culture. In such culture, women have to do footbinding when they were young.

"In cities, girls who come from the gentry class have their feet bounds as early as 
age three... But in our so-so country, girls from families like mine begin their footbinding at age six and it is considered done two years later." (SFTSF:19)

The quotation above shows that every province in China differentiates an age when girls tie their feet. Lily at a young age must obey patriarchal culture. Lily began to tie her feet at the age of six. At the age of six, the feet contain a lot of water so it is easily formed. Foot-binding are complete after they tie their feet for two years. Lily's parents hope by doing foot-binding Lily will have a better future.

"All I know was that foot-binding would make me more marriageable and therefore bring me closer to the greatest love and greatest joy in a woman life - a son. To that end, my goal was to achieve a pair of perfectly bound feet with seven distinct attributes: They should be small, narrow, straight, pointed, and arched, yet still fragrant and soft in texture. Of this requirement, length is more important. Seven centimeters - about the length of a thumb - is the ideal. Shape comes next. A perfect foot should be shaped like the bud of a lotus. It should be full and round at the heel, come to a point at the front, with all weight borne by the big toe alone. This means that the toes and arch of the foot must be broken and bent under to meet the heel. Finally, the cleft formed by the forefoot and heel should be deep enough to hide a large cash piece perpendicularly within its folds. If I could attain all that, happiness would be my reward" (SFTSF:31).

Lily knows that foot-binding is a requirement for Chinese women to get husband. A woman will be successful if she has feet that are perfectly bound. Perfect feet must be shaped like a lotus with a length of seven centimeters. It is said perfectly bound feet if they are small, narrow, straight, pointed, and arched, yet still fragrant and soft in texture. Besides having perfect legs, the greatest happiness in Chinese women's lives is giving birth to a baby boy. If lily manages to reach the size and shape of feet like a lotus flower and can give birth to son, she will get happiness in reward.

The main function of foot-binding for Chinese women was to determine their fate later. When Chinese women had perfect feet, they would be led to a bright future. Neither pretty face nor good body shape guaranteed them a good marriage. The following quotation supports that having tiny feet is much more important than having a pretty face:

"The girl is indeed very lovely, but golden lilies are far more important in life than a pretty face. A lovely face is a gift from Heaven, but tiny feet can improve social standing...... It is not such a bad thing to make a good alliance for a daughter. A high family will bring you better connection, a better bride-price, and long-term political and economic protection" (SFTSF:25).

From the quotation, it is clear that foot size mattered a lot. Besides, the perfectly bound feet were in the shape of a lotus flower. A good shape was a proof that a girl had passed successfully through the agony of foot-binding and therefore she was both disciplined 
and patient. Lily is able to show her discipline to pass it well. She is also patient to endure the pain caused by her rotten feet. Unfortunately, Third sister cannot pass it well because of her confrontation when her feet are bound. The following quotation supports:

"For us, the pain didn't lessen. How could it? But we learned the most important lesson for all women: that we must obey for our own good. Event in those early weeks, a picture began to form of what the three of us would be like as women. Beautiful Moon would be stoic and beautiful in all circumstance. Third Sister would be a complaining wife, bitter about her lot, ungracious about the gifts that were given to her. As for me-the so-called special one-I accepted my fate without argument" (SFTSF:37).

Based on quotation above, foot-binding provides an important lesson for Chinese women to accept all the conditions they experience. The process of foot-binding until the end will have a strong influence on the Chinese women personality. Foot-binding can shape the character of each individual depending on how they endure the pain they experienced. Lily, Beautiful Moon and The Third Sister had to endure pain during the process of binding their feet for their own good. Therefore, a perfect pair of feet is something that Chinese women can be proud of.

Another fact found in the novel is that foot-binding is a motivation for the women to fulfill themselves as member of the society. It is called a motivation because foot-binding led them to be accepted as a true lady. If they have a pair of big feet, they are considered as similar to a maid or the lowest-ranked woman in the household. Of course, a mother wants good things for her daughter so she binds her daughter's feet. Meanwhile, girls must also have a dream of a good future and what she will look like then. Therefore, the mother supports her daughter to succeed in enduring the pain of foot-binding.

"A true lady lets no ugliness into her life," she repeated again and again, drilling the words to me. "Only through pain will you have beauty. Only through suffering will you find peace. I wrap, I bind, but you will have the reward." (SFTSF:38)

By the quotation above, Lily's mother supports her to survive though she has to suffer a lot. Lily's mother gives her a view that she will have everything if she is able to pass it. Beauty, peace, and reward are dreams offered by Lily's mother. Those things become motivations for Lily in reaching her future later. As an ordinary girl, she wants a bright future. She wants to have a husband who comes from a good family, have sons that will make her mother-in-law proud of her and later will be the lady of the household. Not only in the household, may she also become the lady of the village.

\section{Cultural Imperialism}

As declared by Carter (2014) the notion of cultural imperialism implies processes of colonialism and imperialism which poses a relationship of unequal power, which connotes dominance by the West, thereby making the East appear subordinate. The 
dominant cultural products of the society, those most widely disseminated, express the experience, values, goals and achievement of these groups. Cultural products also express the dominant group's perspective on and interpretation of events and elements in the society. The novel Snow Flower and The Secret Fan (2005) which is set in nineteenth century shows the dominant culture of the story in the Chinese culture especially the Patriarchal culture of the way how to treat women and how the women obey the culture. Lily who was born in Yongming province was familiar with the Chinese Patriarchal culture. The women should fulfill the men's satisfaction yet it is opposite with the men's opportunities. The men enjoy their lives ignoring the satisfaction of their wives. It means that women should serve the men all the time. In this case, the slavery is the position of women's life, all of them have to accept the slavish role and this is the law of nature because the stereotype is that the women are the weak one. This kind of thinking is influenced by Confucian ideals which have two main thoughts: Three Obedience and Four Virtues. They live in Confucian society where the world of men and women is very different. This standardizes how a woman must live in her family and society. It doesn't matter whether a woman comes from a poor or rich family. Every woman must obey the rules. It can be proved by the quotation below:

"I also knew the difference between nei- the inner realm of the home- and waithe outer realm of men - lay at the very heart of Confucian society. Whether you are rich or poor, emperor or slave, the domestic sphere is for women and the outside sphere is for men. Women should not pass beyond the inner chambers in their thoughts or in their actions...... I also understood that two Confucian ideals ruled our lives. The first was the Three Obedience: "When a girl, obey your father; when a wife, obey your husband; when a widow, obey your son." The second was the Four Virtues, which delineate women's behavior, speech, carriage, and occupation: "Be chaste and yielding, calm and upright in attitude; be quite and agreeable in words; be restrained and exquisite in movement; be perfect in handiwork and embroidery. "If girls do not stray from these principles, they will grow into virtuous women" (SFTSF:28-29).

By quotation above, Lily knows very well about her role as a woman. She must obey the culture. According by Sarah Ayu Mutia's thesis (2015), it is stated that to bear the status of being a woman and a good wife, a woman must understand and carry out Three Obedience or San Cong (三 从) and Four Virtues or Si De (四 德). Three Obedience or San Cong (三 从) that must be owned by each woman are as follows:

1. Gu Wei Jia Cong Fu (故未嫁从父)： Unmarried women must submit to their parents.

2. Ji Jia Cong Fu (既嫁从父): Married women must submit to their husbands.

3. Fu Si Cong Fu (夫死从子)：When her husband dies, women must submit to sons. 
While the Four Virtues or Si De (四 德) that must be carried out by every woman are:

1. De (德): In moral matters, a woman must have good qualities that are in accordance with the prevailing norms in society. A woman must also be able to position herself.

2. Yan (言): In speaking, a woman must use good and efficient words. Speak as needed and must be polite.

3. Rong (容) : In behave, a woman must obey command and do them well.

4. Gong (工) : In terms of skills, a woman must be good at doing household tasks and skilled at serving her husband.

In the statements, it is very clear that the position of Chinese women are under men. Confucianism is a symbol of culture which is the identity of Chinese society. Chinese society respects Confucianism as the basis of ethics in family and society. Confucianism has an important role in the formation of Chinese female characters in the family and society.

\section{Violence}

Violence is a social conflict that often occurs in society. Usually violence occurs more to women. Women are always victims of violence because they have no strength to fight. Gelles and Straus (1979) define violence as condition where an individual is subjected to random, unprovoked attacks on their property or person where the only motive is to damage, humiliate, or destroy the person for being part of an oppressed group. One of the cases of violence against Chinese women was violence which occurred as a form of patriarchal culture. In nineteen century Chinese culture requires women to do footbindings. This case is illustrated in the Snow Flower novel and the Secret Fan. In the novel Lily experiences violence because she must obey culture.

"Mama washed my feet and rubbed them with alum, to contract the tissue and limit the inevitable secretions of blood and pus. She cut my toenails as short as possible. During this time, my bandages were soaked, so that when they dried on my skin, they would tighten even more. Next, Mama took one end of a bandage, placed it on my instep, and then pulled it over my four smallest toes to begin the process of rolling them underneath my foot. From here, she wrapped the bandage back around my heel. Another loop around the ankle was to get my toes and heel to meet, creating the cleft, but leaving my big toe to walk on" (SFTSF:32).

Through the quotation above, Lily is oppressed by culture because she must obey the rules that required her to tie her feet. Lily's mother started the foot-binding process and Lily obeys without confrontation. The process of binding the feet was done very carefully by the Lily's mother. One false step could result in death. The time needed to produce the desired effect was about two years. In these two years, the girls would feel extreme physical and mental pain. However, it was never felt as a big deal since there was a reward awaiting them. The tradition of foot-bindings was made by Chinese women to run the 
culture from generation to generation from their ancestors. Every Chinese woman must tie her legs for two years to get perfect legs. Eight toes are forced to bend using bandages. The eight toes that are bent will cause fractures in some parts of the toes. One by one the toes that are bent using bandages within two years will experience fractures in all parts of the toes. In old Chinese culture, broken toes is a common thing. However, it causes a feeling of fever sometime after broken toes occurs. As illustrated by the following quotation:

"One day, as I made one of my trips across the room, I heard something crack. One of my toes had broken. I thought the sound was something internal to my own body, but it was so sharp that everyone in the women's camber heard it. My Mother's eyes zeroed in on me. "Move! Progress is finally being made!" Walking, my whole body trembled. By nightfall the eight toes that needed to break had broken, but I was still made to walk. I felt my broken toes under the weight of every step I took, for they were loose in my shoes" (SFTSF:37).

The quotation above shows the condition of Lily's oppression. Lily who had felt a broken on her toes was still forced to walk around her room. The sound of the broken toes was loud but his mother kept telling her to keep going. When the feet detached from the Lily's shoes, Lily's body shivered due to inflammation from the broken toes. All the pain suffered by Lily is forced to be felt to carry out the tradition of ancestral foot-binding. Ancient Chinese culture saw the beauty of women from the shape of their feet. The smaller the foot of the foot-binding, the more perfect the beauty of a woman in Chinese culture.

\section{The Critical Position of the Author}

The last goal of this study is finding the critical position of the author constructed in the novel. The aim of this subchapter is to expose the critical position of the author. Discussing the critical position of the author, interview and biography of Lisa See is necessary to know in order to give an understanding of the author's life. Lisa See was an American writer and novelist who was born in Paris in 1955, but was raised by her mother, writer Carolyn See, in Los Angeles, California. Her father lived in Chinatown and she spent a lot of time there. She as the writer of Snow Flower and The Secret Fan. Lisa See thinks about the discourse of woman oppression happens in $19^{\text {th }}$ century in China. In his work, Lisa See tells a lot about women's lives and Chinese culture. This is an interview with Lisa See:

"I think that I can actually write about the Chinese experience about china in a way because I'm in both worlds and translate that into a way that is not only understood and appreciated by the Chinese community and they can say oh yes this is true this is feels right but that also other people can look at it and understand it and have a window into another culture so build a bridge between these two cultures yeah so if I understand correctly writing about your Chinese background is one thing but talking about it didn't have to answer questions" (Source: Lisa See on Snow Flower and the Secret Fan - The John Adam Institute on 26 ${ }^{\text {th }}$ November 2018). 
Therefore, this research is showing toward China related to the social condition that happened at that time. Snow Flower and The Secret Fan were published in 2005 and consisted of how a 5-year-old Chinese girl tried to survive in a patriarchal culture that required her to tie her feet. At the end of this story, it shows that the main character, Lily, eventually becomes Lady in the husband's house and village. This novel shows that female oppression still exists in the $19^{\text {th }}$ century in China. Lisa See uses Lily's characterization to represent a 5-year-old Chinese woman trying to survive in a patriarchal culture that requires her to commit legs until finally she becomes Lady in the home of her husband and village because her feet are seven centimeters or lotus flowers. There are many discourses in the novel which refer to the issue of woman's oppression.

The novel shows how a 5 year old Chinese girl as the main character in the Chinese culture. Chinese woman had to do a painful tradition of foot-binding. This tradition was initially only followed by women from noble families during the Han dynasty with the aim of showing their social status.

As a part of Chinese society, Lisa See has her own perception toward the social condition happened in $19^{\text {th }}$ century in China. In this case, in Snow Flower and The Secret Fan novel, Lisa See as Chinese women expresses that living in Patriarchal culture in which men were superior to women. It is make women have to obey the culture. Women followed all the rules in order to survive under patriarchal culture. It can be seen of the main characters life in the novel. So, it can be shown of the social condition that portray the character's life, especially about foot-binding.

The end of this story shows that Lily can gain the small leg or lotus flower which is expected by all Chinese women. The success of getting small feet has turned Lily from a poor woman into a rich woman as a Lady in her husband's house and village. However, it is not easy to achieve the success. Lily has to suffer from her childhood until her marriage. Obedience and patience in dealing with suffering make her becomes a woman who is respected in his village. On the other side, foot

binding practice also has great risk. It can causes fatal injury to leg, even causes death.

The position of Lisa See in her novel is negotiating. It is shown in the novel in which woman's oppression happens.

"Mama's dragging Third Sister down the alley," Elder Sister reported..Now we heard Third Sister yell, “No, I won't go, I won't do it!"..Mama scolded her loudly. "You're worthless nothing. You're an embarrassment to our ancestors" (SFTSF:33).

"We should leave her feet open to the air," Mama suggested.."Many of her bones have already broken. If you don't bind them, they will never heal properly. She'll be crippled. Unmarriageable."..."I would rather keep her on this earth unmarried than lose her forever.".."Then she would have no purpose and no value," Aunt reasoned. "Your mother love tells you this is no future."... The whole time they argued, Third Sister didn't move. You can fight it, but once death has grasped hold, nothing can be done" (SFTSF:40). 
"The binding altered not only my feet but my whole character, and in a strange way I feel as though that process continued throughout my life, changing me from a yielding child to a determined girl, then from a young women who would follow without question whatever her in-laws demanded of her to the highest-ranked woman in the country who enforced strict village rules and customs" (SFTSF:2).

In the quotation above, Lisa See described that The Third Sister was forced by her mother. She was forced to do foot-bindings until her legs suffered a fatal injury. In this case, Lisa See tries to describe how dangerous foot-bindings are. She showed that she actually did not agree with the existence of foot-bindings. In her opinion, foot-binding is a tradition of oppression of women. Women are very disadvantaged in this tradition because they have to experience excruciating pain. In other side, success in foot-binding can provide a better life for women and the women who succeed in doing foot-binding will be considered beautiful and will get a rich husband. The condition also happens to Lily's life. She succeeds to gain perfect foot-size and she marries a rich husband and gain better life.

\section{CONCLUSION}

This research discusses about Lisa See's novel entitled Snow Flower And The Secret Fan by using the theory of representation by Stuart Hall which emphasize to find the discourse of woman's oppression especially foot-binding faced by the main character of the novel. It is also supported by using the theory of woman's oppression by Iris Marion Young. These theories are used to analyze the discourse of woman's oppression especially footbinding. In Snow Flower And The Secret Fan novel, there are three kinds of oppression faced by the main character. Those are powerlessness, cultural imperialism, and violence which are done mostly in patriarchal culture. The main character in the novel portrayed the condition of women in the part of village in Patriarchal culture and shows the women's position in Chinese culture which they must obey the culture.

This research uses qualitative research method to analyze the data in the novel related to the main character's woman's oppression especially foot-binding in life. Then, the data are collected by using the documentary method. In this research, there are two kinds of data such as the primary data and the secondary data. The primary data are collected from the narrations, sentences, dialogues in Snow Flower And The Secret Fan written by Lisa See related to the social condition of main character, Patriarchal culture, and foot-binding. The secondary data are information taken from many sources such as, books, journals, literary work reviews, internet and other sources that are related to the real condition of China in the $19^{\text {th }}$ century and the life of the author.

The result of this research shows that Snow Flower And The Secret Fan written by Lisa See represents how the woman's oppression of society in the $19^{\text {th }}$ century. In the $19^{\text {th }}$ century, foot-binding is important for Chinese women to be accepted in the society. Lisa See successfully portrays the issue of woman's oppression especially foot-binding for women as represented through the main character. Lily as the main character in the novel is doing foot-binding to get better life. By doing foot-binding, Chinese women's will get recognition from the community in the form of the lotus feet designation which is believed to be a symbol of Chinese women's beauty. Lisa See wants to reveal how the culture in China in 
$19^{\text {th }}$ century shapes the characteristics of Chinese women in obeying the culture itself. So, foot-binding is important for Chinese women's to be accepted in the society.

\section{BIBLIOGRAPHY}

Blake, E.A. 1989. "The Experience of Powerlessness in Organizations". Concordia University. https://www.researchgate.net/publication/222810203_The_Experience_ of_Powerlessness_in_Organizations Accessed on July 6 ${ }^{\text {th }}, 2019$.

Carter, L. 2014. The Cultural Imperialism Model in International Communication.

Gelles, R.J.A. \& Straus, M. 1979. "Determinants of Violence in the Family: Toward A Theoretical Integration". New York: Free Press.

Hall, S. 1997. Representation: Cultural Representations and Signifying Practices. London, Thousand Oaks, New Delhi: SAGE Publications associated with The Open University.

Levy, H.S. 2001. Chinese Footbinding. Tokyo: John Weatherhill. Inc.

Mutia, S.A. 2015. "Pengaruh Ajaran Confucianisme Terhadap Praktek Footbindingdi Cina". Depok:Universitas Indonesia. http://journal.uny.ac.id/index.php/litera/article/viewFile/1154/9 Accessed on June 22th, 2019.

Rosenlee, L. H. 2006. Confucianism and Women: A Philosophical Interpretation. United States of America: State University of New York Press.

See, L. 2000. on writing Snow Flower. Lisa See's Official Website. http://www.lisasee.com/onwriting.htm Accessed on June 20 th 2019.

See, L. 2005. Snow Flower and the Secret Fan. Edinburgh: Hewer Text UK Ltd.

See, L. Snow Flower and the Secret Fan<i\&gt;. Asiatic: IIUM Journal of English Language and Literature, 10(1), 249-251.Retrieved from https://journals.iium.edu.my/asiatic/index.php/AJELL/article/view/772 Accessed on June 10th, 2019. 